Studia nad Autorytaryzmem i Totalitaryzmem 39, nr 2

\title{
Kilka uwag o prawniczych studiach II stopnia w latach 1952-1954
}

Literatura na temat studiów prawniczych w Polsce lat powojennych nie jest może obfita, ale za to cenna i wiele mówi o kształceniu prawników w okresie budowania podstaw ustroju totalitarnego i rozwijania stalinowskiej indoktrynacji w naszym kraju. Tematem tym zajmowali się m.in. Edward Taylor ${ }^{1}$, Kazimierz Kolańczyk $^{2}$, Zdzisław Ziemba ${ }^{3}$, Witold Wołodkiewicz ${ }^{4}$, Jan Szarycz ${ }^{5}$, Piotr Kładocz$n y^{6}$ i Henryk Olszewski ${ }^{7}$. O szkołach prawniczych, zadaniach prokuratury i szkoleniu kadr wymiaru sprawiedliwości pisali Emil Merc i Jerzy Jodłowski ${ }^{8}$. Z kolei o funkcjonowaniu i losach Centralnej Szkole Prawniczej im. Teodora Duracza

${ }^{1}$ E. Taylor, Poznańskie Studium Ekonomiczne 1919-1949, „Ruch Prawniczy i Ekonomiczny" 20, 1958, z. 1, s. 347 n.

2 K. Kolańczyk, Wydział Prawa Uniwersytetu Poznańskiego (1919-1959), „Ruch Prawniczy i Ekonomiczny" 21, 1959, z. 2, s. 1-32.

${ }^{3}$ Z. Ziemba, Przygotowanie i rozwój kadr sadownictwa Polski Ludowej, [w:] XXV lat wymiaru sprawiedliwości PRL, red. S. Jabłoński, Warszawa 1969, s. 142 n.

${ }^{4}$ W. Wołodkiewicz, Nauczanie prawa - między wymaganiami teorii i praktyki, Warszawa 1991, s. 13 n.; idem, Czy prawo rzymskie będzie istnieć? Uwagi na marginesie nowych prac nad reformowaniem studiów wyższych, „Palestra” 2012, nr 9-10, s. 206 n.

5 J. Szarycz, Sędziowie i sądy w Polsce w latach 1918-1988, Warszawa 1988.

6 P. Kładoczny, Kształcenie prawników W Polsce w latach 1944-1989, „Studia Iuridica” 35, 1998, s. 89-113.

7 H. Olszewski, Wydzial Prawa [Uniwersytetu Poznańskiego] w latach 1919-1990, „Ruch Prawniczy, Ekonomiczny i Socjologiczny" 61, 1999, z. 2, s. 1-16.

8 E. Merc, Szkoły prawnicze, „Demokratyczny Przegląd Prawniczy” (dalej: DPP) 1949, nr 3, s. 5 n.; J. Jodłowski, Akcja szkolenia kadr wymiaru sprawiedliwości, DPP 1946, nr 7, s. 27 n. 
w Warszawie wypowiadali się Igor Andrejew i Marcin Zaborski ${ }^{9}$. Swoiste pojmowanie ludowej praworządności wspominali i akceptowali Leon Chajn i Mieczysław Siewierski ${ }^{10}$.

O studiach II stopnia uruchomionych w roku akademickim 1952 i prowadzonych przez dwa lata pisano mniej, zazwyczaj jako mało ważnym lub wręcz niepotrzebnym epizodzie. Dopiero Dorota Malec w 2013 r. ukazała je w pełniejszym świetle jako logiczną część powojennych reform w kształceniu prawników ${ }^{11}$. W cennym studium ukazała te studia jako zjawisko przejściowe, a zarazem przełomowe. Zaprezentowała je w ciągu przemian w ustroju, na tle ustawodawstwa Polski Ludowej dotyczącego szkolnictwa wyższego. Wykorzystując materiał zgromadzony w Archiwum Uniwersytetu Jagiellońskiego, pozwoliła czytelnikowi zajrzeć za kulisy zjawiska, poznać praktykę i klimat tych studiów. Autorka surowo oceniła studia dwustopniowe; tekst powstał jako ostrzeżenie dla ustawodawcy, aby do nich nie powracać.

Zadaniem, jakie stawia przed sobą autor niniejszego przyczynku, jest poszerzenie danych zebranych przez Dorotę Malec i przedstawienie losów prawniczych studiów II stopnia w latach 1952-1954 w skali krajowej. Stara się on uwzględnić materiał zebrany $\mathrm{w}$ kwerendach archiwalnych ${ }^{12}$ uczelni, które prowadziły takie studia. Sięga też do swojej pamięci, ponieważ sam był studentem Wydziału Prawa Uniwersytetu Poznańskiego na specjalizacji historycznoprawnej.

Prezentację trzeba jednak poprzedzić przynajmniej niektórymi uwagami poprzedników, mówiącymi o „prehistorii” dwustopniowych studiów.

Spory o to, jak kształcić prawników, rozpoczęły się — jak wiadomo - już w pierwszych latach Polski odrodzonej (w 1918 r.). Przeważał pogląd, że powracające do życia państwo potrzebuje ludzi, którzy będą nie tylko znawcami litery prawa, ale będą zdolni do twórczych rozwiązań, wrażliwi na współczesne im trendy oraz umiejący przewidywać rozwój. Takie stanowisko przyjął ustawodawca w 1920 r., który ujednolicał akademickie studia prawnicze; dodatkowo był przyjazny programowi, w którym znalazło się miejsce dla przedmiotów

9 I. Andrejew, Centralna Szkoła Prawnicza im. Teodora Duracza, „Przegląd Prawniczy” 1949, nr 3, s. 7 n.; M. Zaborski, Szkolenie „sędziów nowego typu” w Polsce Ludowej, „Palestra” 1998, nr 1-2, s. 79-92.

${ }^{10}$ L. Chajn, Administracja i sądownictwo w stużbie praworzadności, DPP 1946, nr 8, s. 5 n.; M. Siewierski, O reforme programu akademickich studiów prawnych i ekonomicznych, „Państwo i Prawo" 1946, z. 2, s. 66-67.

11 D. Malec, To już było. Dwustopniowe studia prawnicze. Z dziejów kształcenia prawników w Polsce Ludowej, [w:] Zagadnienia teorii i nauczania prawa karnego. Kara łaczna. Ksiega jubileuszowa Profesor Marii Szewczyk, red. W. Górowski et al., Warszawa 2013, s. 830-845.

12 Autor dziękuje za pomoc w poszukiwaniach pani dr Annie Dziedzic z Archiwum Uniwersytetu Warszawskiego, panu drowi Przemysławowi Żukowskiemu z Archiwum Uniwersytetu Jagiellońskiego, p. NN z Archiwum Uniwersytetu im. Adama Mickiewicza oraz panu prof. drowi hab. Markowi Maciejewskiemu z Uniwersytetu Wrocławskiego. 
historycznych, teoretycznych i filozoficznych ${ }^{13}$. Prawo z 1920 r., kilkakrotnie nowelizowane (po raz ostatni w 1939 r.), obowiązywało do końca II Rzeczypospolitej, choć było przedmiotem ostrych sporów w środowisku akademickim ${ }^{14}$. Wrócono do niego w 1945 r., choć na dłuższą metę okazało się ono nie do zaakceptowania dla rządzących.

Wojna pozostawiła stan prawniczy w spustoszonej kondycji. Straty biologiczne były ogromne. Piotr Kładoczny oblicza, że spośród ok. 3500 sędziów na wydziałach prawa w państwowych szkołach akademickich i prokuratorów przedwojennych zatrudnienie po wojnie znalazło zaledwie ok. $1300^{15}$. Był to także - może nawet przede wszystkim - rezultat nowego ustroju w kraju, którego władcy nie mieli zaufania do starej, „burżuazyjnej” kadry ${ }^{16}$. Stan ten sprawił, że co prawda wrócono do żmudnego, czteroletniego programu kształcenia prawników na wydziałach uniwersyteckich, ale szybko postarano się o ścieżkę skróconą, pozwalającą wypełnić luki kadrowe i potrzeby ideologiczne.

Dekretem z 22 stycznia 1946 r. dopuszczono do obejmowania stanowisk sędziowskich, prokuratorskich, notarialnych i adwokackich przez kandydatów bez studiów wyższych ${ }^{17}$. Jednocześnie rozpoczęto tworzenie średnich szkół prawniczych. Szkoły takie działały w Łodzi (1946-1952), Wrocławiu (1947-1953), Gdańsku (1947-1948), Toruniu (1948-1952), Szczecinie (1950-1951) i Zabrzu (1950-1951) ${ }^{18}$. Ukończenie kursu w szkole prawniczej, w którym przewagę miały przedmioty ideologiczne nad prawniczymi, nie było jednak równoznaczne z uzyskaniem wykształcenia prawniczego, aczkolwiek umożliwiało podjęcie służby asesorskiej w prokuraturze sądownictwie i gwarantowało podjęcie studiów na uniwersyteckim wydziale prawa bez egzaminu wstępnego, z obowiązkiem uzupełnienia łaciny przez tych, którzy nie mieli oceny $z$ tego przedmiotu na świadectwie maturalnym ${ }^{19}$.

13 Por. Rozporządzenie Ministra Wyznań Religijnych i Oświecenia Publicznego z dnia 16 października 1920 r. (Dz.Urz. Ministra Wyznań Religijnych i Oświecenia Publicznego z 1920 r., nr 22, poz. 140).

14 Najbardziej spektakularny z nich toczył się między Oswaldem Balzerem a Juliuszem Makarewiczem, ale dotyczył on przede wszystkim organizacji studiów, a nie ich ogólnohumanistycznego charakteru.

15 P. Kładoczny, op. cit., s. 90.

16 Totalitarne państwo widziało w światopoglądzie prawnika element wrogi socjalistycznej „ludowej” praworządności. Podobnie było — jak wiemy — w III Rzeszy, gdzie prawnik był uważany za urzędnika, któremu brakowało „narodowosocjalistycznego instynktu”, ponieważ stykając się na co dzień z przestępcami, przejmuje ich rozumowanie. Naziści mawiali, że prawnik chciał słyszeć, jak rośnie trawa, a nie zauważał, że przez Niemcy przetacza się rewolucja. Nie inaczej było w ZSRR, gdzie głoszono, że stan prawniczy to reprezentant ideologii burżuazyjnej.

17 Dz.U. Nr 4, poz. 33 z późn. zm.

18 D. Malec, op. cit., s. 833.

19 Ibidem. 
1 czerwca 1948 r. powstała Centralna Szkoła Prawnicza im. Teodora Duracza $\mathrm{w}$ Warszawie ${ }^{20}$, podlegająca ministrowi sprawiedliwości. Placówka, która po dwóch latach uzyskała status państwowej wyższej szkoły zawodowej, miała kształcić w duchu marksizmu. Jej dwuletni program zawierał prawie wszystkie przedmioty prawnicze oraz wszystkie przedmioty ideologiczne; ponadto kadra kierownicza składała się ze zdeklarowanych rzeczników ideologii marksistowskiej $^{21}$. Dorota Malec trafnie ocenia, że szkoła im. T. Duracza, podobnie jak średnie szkoły prawnicze, nie mogła niestety zastąpić rzetelnych studiów prawniczych.

Praktyka nakazywała reformowanie prawniczych studiów uniwersyteckich. Chodziło zarówno o utrzymanie ich ideologicznego charakteru, jak i nasycenie ich treściami stricte prawniczymi. Dekret z 28 października 1947 r. o organizacji nauki i szkolnictwa wyższego ${ }^{22}$ zapewniał, że „badania naukowe są wolne” (art. 1, pkt 1) i że „twórcza praca pozostaje pod szczególną opieką Państwa” (art. 1, pkt 2). Stanowił też, że do zadań szkół wyższych akademickich należy zarówno „organizowanie i prowadzenie badań naukowych” oraz „kształcenie i przygotowywanie kandydatów do naukowej pracy teoretycznej”, jak i „kształcenie kandydatów do zawodów praktycznych, przygotowanych równocześnie do samodzielnej pracy badawczej przy wykonywaniu zawodów praktycznych" (art. 5, pkt 1). Ogólnikowa dyrektywa, nakazująca wprowadzenie swoistego balance między sferą nauki i ideologii, w istocie składała inicjatywę w ręce władzy wykonawczej. Świadectwem takiego stanu rzeczy stało się Rozporządzenie Ministra Oświaty z 23 grudnia 1949 r. w sprawie organizacji i planu studiów na wydziałach prawa w państwowych szkołach akademickich ${ }^{23}$. Dokument ten wprowadzał „dwustopniową organizację studiów w państwowych szkołach akademickich”. Studia I stopnia miały trwać trzy lata i uprawniać do wykonywania „zawodów praktycznych”, dla których wymagane było ukończenie wyższych studiów prawnych, oraz było „warunkiem dopuszczenia do studiów II stopnia”. Ukończenie studiów II stopnia uprawniało do uzyskania „stopnia naukowego”, czyli magisterium.

Paragraf 3 rozporządzenia ministra regulował „ogólny” plan wykładów i ćwiczeń w okresie studiów I stopnia. Przewidywał obowiązkowe wykłady z następujących przedmiotów:

1. na I roku:

- wstęp do nauki o państwie i prawie,

— materializm dialektyczny i historyczny,

- powszechna historia ustrojów państwowych i prawa,

— historia ustroju Polski,

20 W 1950 r. przemianowana na Wyższą Szkołę Prawniczą im. Teodora Duracza (Dz.U. Nr 13, poz. 126).

21 Por. M. Zaborski, op. cit., s. 87.

22 Dz.U. Nr 66, poz. 415.

23 Dz.U. z 1950 r. Nr 6, poz. 58. 
- historia gospodarcza,

- prawo cywilne,

— zagadnienia Polski współczesnej,

- logika;

2. na II roku:

- ekonomia,

- prawo państwowe,

— ustrój ZSRR,

- prawo administracyjne,

- wyznaniowe prawo państwowe,

- prawo cywilne,

— ustrój sądów;

3. na III roku:

- prawo administracyjne,

- skarbowość i prawo skarbowe,

- prawna organizacja przedsiębiorstw,

- prawo pracy ubezpieczeń społecznych,

- prawo międzynarodowe publiczne,

- postępowanie karne,

- postępowanie cywilne i

- prawo rzymskie (prywatne).

W ciągu każdego roku student zobowiązany był do zaliczenia 120 godzin ćwiczeń. Zasługuje na uwagę, że wśród zalecanych ćwiczeń figurowały aż trzy przedmioty historycznoprawne: powszechna historia ustrojów państwowych i prawa, historia ustroju Polski oraz historia gospodarcza. Dodać trzeba, że studiowanie prawa przy obowiązującym rozporządzeniu wymagało też od mężczyzn udziału w cotygodniowych całodziennych zajęciach studium wojskowego i zajęć wychowania fizycznego. Program ten, z niewielkimi korektami dokonywanymi przez rady wydziału za zgodą resortu, obowiązywał do drugiej połowy lat $50 .{ }^{24}$ Rozporządzenie zapowiadało bowiem uregulowanie organizacji i planu studiów II stopnia odrębnymi przepisami. W istocie resort porządkował wiele spraw prawem ,powielaczowym”, przykładając wiele uwagi do utrzymania ich pod ścisła kontrolą.

24 Okres ten podsumowywała Ustawa z 15 grudnia 1951 r. o szkolnictwie wyższym i pracownikach nauki (Dz.U. z 1952 r. Nr 6, poz. 38). Ustawa, będąca odwzorowaniem regulacji sowieckich — zwłaszcza w zakresie regulacji dotyczących stopni i tytułów naukowych, głosiła w art. 1: „Szkoły wyższe, kształcąc i wychowując kadry inteligencji ludowej w duchu ofiarnej służby ojczyźnie, walki o pokój i socjalizm: 1) przygotowują pracowników o najwyższym poziomie kwalifikacji zawodowych, 2) przygotowują pracowników zdolnych do samodzielnego naukowego przy wykonywaniu swego zawodu, 3) kształcą pracowników nauki i przygotowują ich do pracy dydaktycznej i badawczo-naukowej, 4) organizują i prowadzą badania naukowe, 5) biorą udział w upowszechnianiu nauki techniki oraz w szerzeniu naukowego poglądu na świat. 
Dwustopniowe studia wprowadzono w życie w roku akademickim 1952/1953 na większości wydziałów uniwersyteckich. Pismem z dnia 31 maja 1952 r. określono specjalizacje, jakie mogły prowadzić poszczególne placówki²5. Z wydziałów prawa tylko Uniwersytet Warszawski otrzymał prawo do wszystkich specjalizacji, czyli teorii państwa i prawa, prawa administracyjnego, prawa cywilnego, prawa karnego, prawa finansowego, prawa międzynarodowego publicznego i historii państwa i prawa. Natomiast Uniwersytet Jagielloński mógł prowadzić dwustopniowe studia tylko w zakresie prawa karnego ${ }^{26}$, Uniwersytet Wrocławski - w zakresie prawa cywilnego i administracyjnego (w roku akademickim 1953/1954 także w zakresie prawa karnego i finansowego), a Uniwersytet Poznański - tylko w zakresie historii państwa i prawa ${ }^{27}$. Do wspomnianego pisma z 31 maja 1952 r. dołączono instrukcję Departamentu Studiów Uniwersyteckich, ustalającą tryb naboru na studia ${ }^{28}$. Ministerstwo jeszcze raz skrupulatnie wyliczało zasady rekrutacji. Na prawnicze studia magisterskie mogli zostać przyjęci kandydaci, którzy uzyskali dyplom studiów I stopnia, osiągnęli w czasie studiów przynajmniej dobre wyniki w nauce (ogólna nota nie gorsza niż dobra), wykazali się w czasie studiów I stopnia uzdolnieniami i zamiłowaniem do prac naukowo-badawczych, w szczególności w kierunku obranej specjalizacji, oraz odznaczali się dobrą postawą społeczno-polityczną. Pierwszeństwo w przyjęciu na studia należało do studentów pracujących w charakterze zastępców asystentów i pracowników naukowych instytutów naukowo badawczych. Ministerstwo nie wyjaśniało jednak, co należy rozumieć przez dobrą postawę społeczno-polityczną i do kogo należało stwierdzenie tej okoliczności. Opinie były pisane z reguły przez studentów-członków partii lub — i to miało miejsce częściej — przez aktywistów Związku Młodzieży Polskiej III roku studiów. Ich opinie — w wielu przypadkach dyskwalifikujące, powodujące odrzucenie kandydata na studia magisterskie — na ogół nie przekonywały członków wydziałowej komisji kwalifikacyjnej ${ }^{29}$. Rzetelnej selekcji kandydatów sprzyjał fakt, że wśród ubiegających się przeważali seminarzyści z dobrą opinią kierowników katedr. Znaczenie miała też okoliczność, że skład komisji był rygorystycznie określony. Tworzyli ją urzędujący dziekan, prodziekan jako jego zastępca, kierownicy katedr prowadzących seminaria z dziedzin uznanych za specjalizacje na otwieranych studiach magisterskich, przedstawiciel zakładowej organizacji związkowej oraz delegat pomocniczych

25 Wykaz i lokalizacja specjalności na studiach uniwersyteckich II stopnia (por. Arch. UJ WP IV 128).

26 W roku akademickim 1953/1954 uruchomiono na UJ dodatkowo specjalizację z prawa finansowego, prawa finansowego oraz historii państwa i prawa.

27 W roku akademickim 1953/1954 na UP uruchomiono dodatkowo specjalizację z prawa administracyjnego.

28 W niniejszym tekście wykorzystano materiał przesłany do rektora UJ (Arch. UJ SM 252).

29 Pamiętam, że w trakcie rozmów kwalifikacyjnych większość opiniujących miała już nakazy pracy w kieszeni i nie uczestniczyła w pracach komisji. 
pracowników nauki (jako sekretarz). Przedstawiciel Zrzeszenia Studentów miał głos doradczy, podobnie jak opiekun grupy.

Przykładowo w skład wydziałowej komisji kwalifikacyjnej na Uniwersytecie Jagiellońskim wchodzili zarówno w 1952/1953, jak i w 1953/1954 najbardziej znani profesorowie: dziekan Michał Patkaniowski, prodziekan Antoni Walas oraz członkowie komisji: Jerzy Lande, Szczęsny Wacholz, Kazimierz Przybyłowski, Władysław Wolter, Karol Ostrowski, Ludwik Ehrlich i Adam Vetulani oraz magistrzy: Kazimierz Buchała (z ramienia pomocniczych pracowników nauki) i Marek Sobolewski (jako przedstawiciel ZOZ) ${ }^{30}$. Natomiast na Wydziale Prawa Uniwersytetu Poznańskiego, na którym przez dwa lata prowadzono wyłącznie specjalizację historycznoprawną, komisji przewodniczył dziekan Marian Zimmermann, jego zastępcą był prodziekan Alfons Klafkowski, a członkami profesorowie Michał Sczaniecki, Zdzisław Kaczmarczyk, Kazimierz Kolańczyk, Bogdan Lesiński i Bolesław Wiewióra ${ }^{31}$. Z kolei na Uniwersytecie Warszawskim w skład wydziałowej komisji kwalifikacyjnej, której przewodniczył prof. Jan Wasilkowski, wchodzili m.in. Juliusz Bardach, Władysław Sobociński, Jakub Sawicki oraz Bogusław Leśnodorski.

Liczby studiujących na II stopniu nie były stałe, choć ministerstwo usiłowało narzucić rygorystyczne limity. Autor niniejszej pracy ocenia, że ogółem na czterech wydziałach prawa przez studia II stopnia w latach 1952-1954 przewinęło się ok. 150-200 studentów. W toku obu lat akademickich zmieniały się specjalizacje, przenoszono studentów z jednego uniwersytetu na drugi oraz pisano odwołania, w rezultacie których ministerstwo powiększało limity. W kilku przypadkach pierwotne limity narzucone poszczególnym wydziałom nie zostały wykorzystane ${ }^{32}$. W Poznaniu prawnicze studia dwustopniowe prowadzono z historii państwa i prawa dla 8 (w roku akademickim 1952/1953) i dla 12 studentów (w roku akademickim 1953/1954), natomiast w zakresie prawa administracyjnego — dla 16

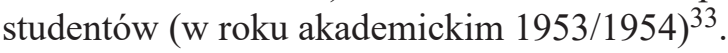

Program prawniczych studiów II stopnia był ustalony centralnie i oczywiście obejmował przedmioty ideologiczne i to $\mathrm{w}$ absurdalnym wymiarze: materializm dialektyczny i historyczny w wymiarze 120 godzin, teorię państwa i prawa w wymiarze 60 godzin, historię ustroju ZSRR w wymiarze 60 godzin oraz ekonomię polityczną $\mathrm{W}$ wymiarze 120 . Uwzględniał jednak przede wszystkim dyscypliny podstawowe dla obranej specjalizacji, a ponadto liczył się z możliwościami kadrowymi wydziału. Trzeba bowiem przyznać, że wykładowcami bywali uczeni

30 Arch. UJ SM 252.

31 Protokót Senatu UP, Kronika Uniwersytetu Poznańskiego 1945/45-1954/55, Arch. UAM, protokoły senatu.

32 Charakterystyczne było, że resortowi nie udało się uruchomić specjalizacji z zakresu teorii prawa. W sprawozdaniach dziekanów powtarzano, że nie było ani jednego kandydata na studia w zakresie filozofii marksistowskiej.

33 Zob. Kronika Uniwersytetu Poznańskiego za lata 1945-1955, Poznań 1956. 
— jak dziś mawiamy — „Z najwyższej półki”. Autor pracy pozwala sobie przypomnieć nazwiska prowadzących wykłady na studiach II stopnia o specjalizacji historycznoprawnej. Na Uniwersytecie Warszawskim wykładali Bogusław Leśnodorski (prawo Księstwa Warszawskiego i Królestwa Polskiego), Juliusz Bardach (ustrój prawa rosyjskiego), Karol Koranyi (prawo sądowe od początku epoki feudalnej do początku XIX w.), Jakub Sawicki (nauki pomocnicze historii państwa i prawa) i Edward Gintowt (proces rzymski cywilny [dla prawników — romanistów]). Dodatkowo trzeba było odbyć lektoraty z łaciny i języka rosyjskiego ${ }^{34}$. Ukoronowaniem studiów było napisanie pracy magisterskiej i złożenie egzaminu magisterskiego. Uzasadniając ten program, J. Bardach oceniał w piśmie okólnym:

Specjalizacja historyczno-prawna na drugim stopniu studiów ma przygotować studenta do pracy zawodowej w zakresie archiwistyki prawniczej i naukowego bibliotekarstwa. Jednocześnie ma ona pogłębić wiadomości słuchaczy w zakresie interesujących ich przedmiotów (prawo polskie epoki kapitalizmu i romanistyka), a także rozszerzyć ich wiadomości w zakresie historii powszechnej, prawa sądowego i historii prawa rosyjskiego. Ma to na celu przygotowanie szczególnie uzdolnionych studentów do dalszych studiów naukowych (aspirantura). Nie zaprojektowano seminariów z wąskich specjalności. Studenci drugiego stopnia będą uczęszczać na seminaria wspólnie z magistrami przygotowującymi się do uzyskania stopnia naukowego. Umożliwi to dyskusję naukową w szerszym gronie i na wyższym poziomie ${ }^{35}$.

Na Uniwersytecie Jagiellońskim wykładali Michał Patkaniowski (historia prawa karnego i procesowego), Adam Vetulani (źródła do historii państwa i prawa polskiego; historia polskiego prawa sądowego) oraz Wacław Osuchowski (historia źródeł prawa rzymskiego; historia rzymskiego procesu cywilnego). Oferta UJ zawierała także wykłady monograficzne oraz lektorat $\mathrm{z}$ języka zachodnioeuropejskiego ${ }^{36}$.

34 Arch. UW WPA 79.

35 Ibidem.

36 Arch. UJ SM 252. W uzasadnieniu dla wykładu historia prawa rosyjskiego J. Bardach wymieniał wykładane problemy: „Znaczenie badań nad prawem rosyjskim dla historii prawa polskiego. Polscy historycy prawa badacze dawnego prawa rosyjskiego: Rakowiecki, Maciejowski, Huber. Problem badań porównawczych praw słowiańskich w świetle pracy Stalina”; „O marksizmie w językoznawstwie Stalina”; „Problem samodzielności rozwoju ustrojowo-prawnego Słowian wschodnich”; „Fałszywa teoria burżuazyjna »młodszości kulturalnej«”; „Pierwsze pomniki prawa ruskiego: umowy międzynarodowe z Bizancjum $(901,911,944)$ i najstarsza »Prawda Ruska«"; ,„Prawda Ruska« — pomnik kultury prawniczej Rusi Kijowskiej. Jej układ, treść i źródła”; „Miejsce »Prawdy Ruskiej« wśród prawodawstw słowiańskich”; „Związki najstarszego prawa ruskiego z prawem polskim Księgi Elbląskiej i Statutów Kazimierza Wielkiego”; „Pskowskaja sudnaja pramota jako pomnik prawa rosyjskiego Rusi północno-zachodniej. Jego źródła, układ i treść”; „Sudieb NIK 1496 r. Prawolitewskie i jego ruskie źródła: Sudiebnik Kazimierza Jagiellońcvzyka (1468) i I Statut litewski (1529)”; „Dalszy rozwój prawa litewskiego. Drugi »Sudiebnik« 1550 r. i „»Stogław«. Ich źródło, układ i treść”; „Rozwój prawa rosyjskiego w XVI wieku”; „Sobornoje ułożenie 1649 r. Wielka kodyfikacja dawnego prawa rosyjskiego. Jego źródła i związek z III Statutem Litewskim"; „Samodzielny rozwój prawa rosyjskiego"; „Soborne ułożenie — kodeks monarchii feudalno-pańszczyźnianej”; „Prawo ustawowe a prawo zwyczajowe w Rosji. Dalszy rozwój prawa rosyjskiego”

Studia nad Autorytaryzmem i Totalitaryzmem 39, nr 2, 2017

(C) for this edition by CNS 
Na Uniwersytecie Wrocławskim wykładowcami byli Seweryn Wysłouch (historia państwa i prawa polskiego), Michał Wyszyński (prawo rzymskie) i Iwo Jaworski (powszechna historia państwa i prawa) ${ }^{37}$. Na Uniwersytecie Poznańskim zajęcia prowadzili Zdzisław Kaczmarczyk (historia źródeł polskiego prawa), Józef Matuszewski (zarys nauk pomocniczych historii), Michał Sczaniecki (historia państwa i prawa zachodniopomorskiego) oraz Marian Z. Jedlicki (historia państwa i prawa Rusi i Rosji), który w marcu 1954 r. niespodziewanie zmarł.

Atmosfera studiów była dobra; w elitarnym, dwunastoosobowym gronie a tylu, jak już zostało wspomniane, było nas na specjalizacji historycznoprawnej w Poznaniu w roku akademickim 1953/1954 - czuliśmy się wyróżnieni i zmotywowani do nauki. Mogliśmy nie tylko słuchać mądrych wykładów, lecz także dyskutować z profesorami. Znaliśmy ich dobrze, bo od dwóch lat uczęszczaliśmy na ich proseminaria i seminaria. Część z nas miała już zaawansowane prace magisterskie. Wielu miało nadzieję na asystenturę $\mathrm{w}$ jednej z katedr lub na aspiranturę, którą miano uruchomić w Warszawie. Niektórzy brali już udział w pracach administracyjnych w katedrach. Ponadto razem z wybrańcami z młodszego rocznika studiów tworzyliśmy koło naukowe, które prowadzili wspólnie profesorowie Z. Kaczmarczyk i M. Sczaniecki. Rezultatem naszych kilkumiesięcznych poszukiwań i debat było zbiorowe, ponadstustronicowe opracowanie O zrastaniu się Prus Królewskich z Rzeczpospolita w latach 1444-1525. Praca powstała w ramach ogłoszonego przez ministerstwo konkursu na pracę naukową lub popularnonaukową z okazji ogłoszenia roku 1954 Rokiem Odrodzenia, została przez nas przedstawiona na sesji naukowej wydziału i doczekała się II nagrody ministerstwa ${ }^{38}$. Przedmioty ideologiczne nie wprawiały nas w zachwyt, ale dyskomfort zmniejszała więź koleżeństwa i sympatii z wykładowcami, choć Władysław Markiewicz i Adam Łopatka nie byli zapiekłymi dogmatykami, raczej cytowali klasyków, niż ich interpretowali. Trochę inaczej było tylko w trakcie zajęć z ekonomii politycznej. Warto podkreślić, że Rada Wydziału Prawa i akademicki Senat UP kilka razy pochlebnie wyrażali się o studentach II stopnia na wydziale prawa. Zastrzeżenia dotyczyły wyłącznie naszej niedoskonałej znajomości średniowiecznej łaciny, co przeszkadzało w opanowaniu nauk pomocniczych historii, czyli paleografii, genealogii sfragistyki, bibliografii i dyplomatyki ${ }^{39}$.

Spróbujmy podsumować powyższe wywody. Oczywiste, że u źródeł powołania prawniczych studiów II stopnia na wydziałach prawa tkwiły — podobnie jak

(Arch. UW WPA 77). Program J. Bardacha był mistrzowskim wcieleniem niezbędnego w owym czasie kompromisu.

37 Zob. Uniwersytet Wrocławski 1945-1970. Księga jubileuszowa, red. W. Flora, Wrocław 1970, s. 116.

38 Por. H. Olszewski, Z prac Studenckiego Koła Naukowego historyków prawa Uniwersytetu Poznańskiego, [w:] Studia i Materiały do Dziejów Wielkopolski i Pomorza, red. Z. Kaczmarczyk, t. 1, Poznań 1956, s. 283-285. Pierwszą nagrodę zdobył Stanisław Grzybowski z UJ za pracę: Adam Sienicki-Demostenes sejmów polskich.

39 Protokoty Senatu i Rady Wydziatu UP, arch. UAM, s. 18. 
na innych wydziałach uniwersyteckich - motywacje polityczne. Ich naturalnym rezultatem było skrócenie studiów I stopnia do lat trzech, co ujemnie ciążyło na zakresie zdobywanej wiedzy i przyczyniało się do niezadowolenia większości studiujących, budząc w nich poczucie, że opuszczają uczelnię niedokształceni, ponadto $\mathrm{z}$ nakazami pracy $\mathrm{w}$ ręku i nie zawsze pozytywnymi opiniami wystawianymi przez uczelniane instancje partyjne. Kierowani byli często, wbrew swojej woli, do stanowisk w aparacie administracji, w prokuraturze czy w służbach bezpieczeństwa. Równie oczywiste jest jednak, że prawnicze studia dwustopniowe miały w swoim czasie także ewidentne zalety. Dzięki nim wielu prawników mogło wejść na drogę badań naukowych. Należą do nich m.in. znani i cenieni przedstawiciele nauk prawnych, znawcy prawa cywilnego, karnego i administracyjnego, tacy jak profesorowie Józef Filipek, Włodzimierz Piotrowski, Wiktor Sokolewicz, Andrzej (?) Rajski, Adam Strzembosz, Anna Turska czy Sylwester Wójcik.

Autor pragnie bliżej zilustrować rolę, jaką studia II stopnia z lat 1953/1954 odegrały w dziejach dyscyplin historycznoprawnych. Stwierdza, że umożliwiły one naukowy start prawie całej generacji historyków prawa, rozpoczynających karierę po wojnie. Uwzględniając ich w porządku alfabetycznym, podając rok i miejsce ukończenia studiów II stopnia, nazwisko mistrza, którym z reguły, ale nie zawsze był promotor doktoratu, specjalizację, tytuły pracy doktorskiej i habilitacyjnej, skrócony materiał bibliograficzny, wymienia najważniejszych:

1. Andrzej Ajnenkiel (1931-2015), absolwent studiów II stopnia w roku 1953/1954 na Uniwersytecie Warszawskim, profesor zwyczajny historii ustroju i prawa w Instytucie Historii Polskiej Akademii Nauk, badacz historii ustroju i prawa w II Rzeczypospolitej, autor doktoratu pod kierunkiem Juliusza Bardacha pt. Położenie prawne robotników rolnych w Polsce 1918-1939 (1962) oraz habilitacji: Spór o model parlamentaryzmu polskiego do roku $1926(1972)^{40}$.

2. Władysław Ćwik (1929-2009), absolwent studiów II stopnia na Uniwersytecie Warszawskim w roku 1952/1953, profesor zwyczajny na Uniwersytecie Rzeszowskim, badacz historii ustroju i prawa Polski, autor doktoratu pod kierunkiem Józefa Mazurkiewicza pt. Miasta królewskie Lubelszczyzny w XVIII w. (1961) oraz habilitacji: Pozostałości feudalne w miastach rządowych małopolskich terenów Królestwa Polskiego 1815-1861 (1988) ${ }^{41}$.

3. Krzysztof Dembski (1932-1992?), absolwent studiów II stopnia na Uniwersytecie Poznańskim w roku 1952/1953, badacz historii ustroju Polski, autor doktoratu pod kierunkiem Zdzisława Kaczmarczyka pt. Wielkopolska w procesie budowy II Rzeczypospolitej (1968) oraz habilitacji: Państwo a Kościót w PRL (maszynopis 1992).

40 Wspomnienie: H. Olszewski, Profesor Andrzej Ajnenkiel (1931-2015), „Czasopismo Prawno-Historyczne" 67, 2015, z. 2, s. 361-364.

41 Wspomnienie: W. Witkowski, Władysław Ćwik (1929-2009), „Czasopismo Prawno-Historyczne" 62,2010 , z. 2, s. 479-481. 
4. Karol Jonca (1930-2008), absolwent studiów II stopnia w roku akademickim 1953/1954, profesor zwyczajny Uniwersytetu Wrocławskiego, nauk politycznych i prawnych Uniwersytetu Wrocławskiego, historyk ustroju i idei, badacz historii totalitaryzmu faszystowskiego i historii Śląska, autor doktoratu pod kierunkiem Seweryna Wysłoucha pt. Położenie robotników w przemyśle górniczo-hutniczym na Śląsku w latach 1889-1914 (1962) oraz habilitacji: Polityka socjalna Niemiec w przemyśle ciężkim Śląska 1871-1914 (1966) ${ }^{42}$.

5. Wiesław Litewski (1933-2004), absolwent studiów II stopnia w roku 1953/1954, profesor zwyczajny Uniwersytetu Jagiellońskiego, badacz prawa rzymskiego, wieloletni kierownik Katedry Prawa Rzymskiego Uniwersytetu Jagiellońskiego, autor doktoratu pod kierunkiem Wacława Osuchowskiego pt. Beneficium competentiae $w$ prawie rzymskim (1963) oraz habilitacji: Die roemische Appellation in Zivilsachen $(1966)^{43}$.

6. Jan Malarczyk (1931-1998), absolwent studiów II stopnia w roku 1953/1954 na Uniwersytecie Warszawskim, profesor zwyczajny Uniwersytetu Marii Curie-Skłodowskiej w Lublinie, uczeń Grzegorza Leopolda Seidlera, wieloletni kierownik Katedry Historii Doktryn Politycznych i Prawnych, badacz renesansu i dziejów nauki, kandydatura nauk na Uniwersytecie w Leningradzie, habilitacja: $U$ źródeł włoskiego realizmu politycznego. Machiavelli i Guiciardini $(1963)^{44}$.

7. Jerzy Młynarczyk (ur. 1931), absolwent studiów II stopnia na Uniwersytecie Poznańskim w roku 1953/1954, uczeń Mariana Z. Jedlickiego, profesor zwyczajny na Uniwersytecie Gdańskim, badacz prawa cywilnego i prawa morskiego, autor habilitacji: Umowa o budowe statku morskiego (1978).

8. Henryk Olszewski (ur. 1932), absolwent studiów II stopnia na Uniwersytecie Poznańskim w roku akademickim 1953/1954, badacz ustroju Polski i historii Niemiec XIX i XX w., wieloletni kierownik Katedry Historii Doktryn Politycznych i Prawnych Uniwersytetu im. Adama Mickiewicza w Poznaniu, autor doktoratu pod kierunkiem Zdzisława Kaczmarczyka pt. Ustrój i prawo w pogladach szlachty w Rzeczpospolitej 1697-1740 (1959) oraz habilitacji: Sejm Rzeczypospolitej epoki oligarchii magnackiej 1652-1663. Prawo - praktyka - teoria programy (1966).

9. Stanisław Płaza (1927-2006), absolwent studiów II stopnia na Uniwersytecie Jagiellońskim w roku 1953/1954, profesor zwyczajny Uniwersytetu Jagiellońskiego, badacz historii ustroju i prawa Polski, wydawca źródeł, wieloletni kierownik Katedry Historii Państwa i Prawa Polskiego, autor doktoratu pod kierunkiem Adama Vetulaniego pt. Sąy wójtostwa na wsiach Sądecczyzny

42 Wspomnienie: H. Olszewski, Ludzie uniwersytetu w mojej pamięci, Poznań 2015.

43 Wspomnienie: J. Reszczyński, Wiesław Litewski (1933-2004), „Czasopismo Prawno-Historyczne" 57, 2005, z. 1, s. 443-448.

44 Wspomnienie: L. Dubel, Jan Malarczyk (1931-1998), „Czasopismo Prawno-Historyczne" 51, 1999, z. 1-2, s. 501-503. 
w XVI-XVIII w. (1964) oraz habilitacji: Próby reform ustrojowych $w$ czasach pierwszego bezkrólewia 1572-1574 (1969) ${ }^{45}$.

10. Stanisław Russocki (1930-2002), absolwent studiów II stopnia na Uniwersytecie Warszawskim w roku 1952/1953, profesor zwyczajny Uniwersytetu Warszawskiego polskiego, badacz ustroju i prawa wieków średnich, autor doktoratu w Katedrze Historii Państwa i Prawa pod kierunkiem Juliusza Bardacha pt. Formy władania ziemia w prawie ziemskim Mazowsza (1960) oraz habilitacji: Protoparlamentaryzm Czech do poczatku XV w. $(1973)^{46}$.

11. Stanisław Salmonowicz (ur. 1931), absolwent studiów II stopnia Uniwersytetu Warszawskiego w roku akademickim 1953/1954, profesor zwyczajny Uniwersytetu Mikołaja Kopernika w Toruniu, wieloletni kierownik Katedry Powszechnej Historii Państwa i Prawa, badacz ustroju, prawa i idei wieku oświecenia i rewolucji francuskiej, autor doktoratu pod kierunkiem Karola Koranyiego pt. Krystian Bogumit Steiner (1746-1814), prawnik, historyk i literat polskiego Oświecenia (1960) oraz habilitacji: Prawo karne oświeconego absolutyzmu. Z dziejów kodyfikacji karnych przełomu XVIII i XIX w. (1966) ${ }^{47}$.

12. Bogdan Sobol (1929-1999), absolwent studiów II stopnia Uniwersytetu Warszawskiego w roku 1952/1953, archiwista, badacz późnego średniowiecza, uczeń J. Sawickiego, autor doktoratu pod kierunkiem Juliusza Bardacha pt. Sejm i sejmiki ziemskie Mazowsza Książęcego (1967) oraz habilitacji: O podstawie prawnej stosowania statutów $i$ zwyczajów sądowych na Mazowszu w latach 1532-1794 (1971) $)^{48}$.

13. Katarzyna Sójka-Zielińska, absolwentka studiów II stopnia na Uniwersytecie Warszawskim w roku 1953/1954, profesor zwyczajny, wieloletni kierownik Katedry Powszechnej Historii Państwa i Prawa UW, badaczka historii ustroju i prawa i idei XIX i XX w., doktorat pt. Fideikomisy familijne $w$ prawie pruskim XIX wieku (1960), habilitacja: Prawne problemy podziału gruntów chtopskich Galicji na tle austriackiego ustawodawstwa $(1966)^{49}$.

45 Wspomnienie: W. Uruszczak, Stanisław Płaza (1927-2006), „Czasopismo Prawno-Historyczne" 58, 2006, z. 1, s. 323-327. Tamże bibliografia autorstwa W. Pęksy.

46 J. Bardach, Stanisław Russocki - badacz dziejów ustroju i prawa, [w:] idem, W obiektywie nauki $i$ w lustrze pamięci, red. W. Sudnik, Warszawa 2004; H. Olszewski, Ludzie Uniwersytetu mojej pamięci...

47 D. Janicka, Jubileusz profesora Stanistawa Salmonowicza, „Czasopismo Prawno-Historyczne" 54, 2002, z. 2, s. 362-366; S. Salomonowicz, Życie jak osioł ucieka. Wspomnienia, Gdańsk 2014.

48 Wspomnienie: J. Bardach, Bogdan Sobol (1929-1999), „Czasopismo Prawno-Historyczne" 52, 2000, z. 1-2, s. 429-430.

49 D. Janicka, Uroczystość odnowienia doktoratów Profesor Katarzyny Sójki-Zielińskiej i Profesora Stanisława Salmonowicza w Uniwersytecie Warszawskim, „Czasopismo Prawno-Historyczne" 64, 2012, z. 2, s. 423-424; M. Wąsowicz, Laudacja w związku z odnowieniem doktoratów Profesor Katarzyny Sójki-Zielińskiej i Profesora Stanisława Salmonowicza, „Czasopismo Prawno-Historyczne" 64, 2012, z. 2, s. 425-431. 
14. Michał Staszków (1929-1992), absolwent studiów II stopnia Uniwersytetu Warszawskiego w roku 1953/1954, badacz prawa rzymskiego, prawa wynalazczego i patentowego, profesor zwyczajny Uniwersytetu Śląskiego, wieloletni kierownik Katedry Prawa UŚ, autor doktoratu pt. Vim dicere. Studia nad geneza prawa rzymskiego (1961) oraz habilitacji: Komuna $w$ doktrynie prawnej XII-XIV w. (1968).

15. Stanisław Waltoś (ur. 1932), absolwent studiów II stopnia Uniwersytetu Jagiellońskiego w roku akademickim 1953/1954, profesor zwyczajny i wieloletni kierownik Katedry Postępowania Karnego, dyrektor Muzeum UJ, badacz prawa karnego materialnego i procesowego karnego oraz historyk prawa i kultury, napisał doktorat pod kierunkiem Mariana Cieślaka pt. Funkcje i formy aktu oskarżenia w procesie karnym (1963) oraz habilitację: Model postępowania przygotowawczego na tle prawno-porównawczym $(1968)^{50}$.

Było to pokolenie badaczy, które dzięki studiom II stopnia na wydziałach prawa potrafiło w dużej mierze wypełnić lukę pozostawioną przez mistrzów, którzy stworzyli główne zręby nauk historii prawa przed II wojną światową, i kontynuować dzieło tych, którzy je rozwijali w pierwszych latach powojennych.

Studia dwustopniowe zakończyły swój byt po dwóch latach, kiedy przywrócono jednolite studia prawnicze. Końcowym akordem było Zarządzenie Ministra Szkolnictwa Wyższego z dnia 31 grudnia 1953 r. w sprawie warunków ukończenia studiów II stopnia na uniwersytetach ${ }^{51}$. Trwałą zdobyczą studiów dwustopniowych miało być jednak utrzymanie obowiązku napisania pracy magisterskiej i złożenie egzaminu magisterskiego. W stosunku do tych, którzy właśnie kończyli II rocznik studiów II stopnia, zarządzenie przewidywało również utrzymanie praktyki nakazów pracy stosownie do przepisów Ustawy z dnia 7 marca $1950 \mathrm{r}$. o planowym zatrudnianiu absolwentów średnich szkół zawodowych oraz szkół wyższych ${ }^{52}$. Po kilku latach ministerstwo zorganizowało zaoczny eksternat, który umożliwiał uzyskanie dyplomu magistra prawa po złożeniu pracy magisterskiej i wyrównaniu różnic programowych. Zarówno eksternistów, jak i studentów utworzonego w 1956 r. studium zaocznego czekał wielki wysiłek.

\section{Bibliografia}

Andrejew I., Centralna Szkoła Prawnicza im. Teodora Duracza, „Przegląd Prawniczy” 1949, nr 3. Bardach J., Stanisław Russocki - badacz dziejów ustroju i prawa, [w:] idem, W obiektywie nauki $i$ w lustrze pamięci, red. W. Sudnik, Warszawa 2004.

Bardach J., Bogdan Sobol (1929-1999), „Czasopismo Prawno-Historyczne” 52, 2000, z. 1-2.

${ }^{50}$ Historyk prawa i kultury Stanisław Waltoś jest autorem monografii: Owoce zatrutego drzewa. Procesy $i$ wydarzenia, które wstrzasnęty prawem (Kraków 1978), Na tropach doktora Fausta i inne szkice (Warszawa 2004) i Grabież ołtarza Wita Stwosza (Warszawa 2015).

51 M.P. z 1954 r. Nr 7, poz. 167.

52 Dz.U. Nr 10, poz. 106. 
Chajn L., Administracja i sądownictwo w stużbie praworzadności, „Demokratyczny Przegląd Prawniczy" 1949, nr 3.

Dubel L., Jan Malarczyk (1931-1998), „Czasopismo Prawno-Historyczne” 51, 1999, z. 2.

Janicka D., Uroczystość odnowienia doktoratów Profesor Katarzyny Sójki-Zielińskiej i Profesora Stanisława Salmonowicza w Uniwersytecie Warszawskim, „Czasopismo Prawno-Historyczne” 64, 2012, z. 2.

Jodłowski J., Akcja szkolenia kadr wymiaru sprawiedliwości, „Demokratyczny Przegląd Prawniczy”, $1946, \mathrm{nr} 7$.

Kładoczny P., Kształcenie prawników w Polsce w latach 1944-1989, „Studia Iuridica” 35, 1998.

Kolańczyk K., Wydział Prawa Uniwersytetu Poznańskiego 1919-1959, „Ruch Prawniczy i Ekonomiczny" 21, 1958, z. 1.

Kronika Uniwersytetu Poznańskiego za lata 1945-1955, Poznań 1956.

Malec D., To już było. Dwustopniowe studia prawnicze. Z dziejów kształcenia prawników w Polsce Ludowej, [w:] Zagadnienie teorii i nauczania prawa karnego. Kara Łaczna. Ksiega Jubileuszowa Profesor Marii Szewczyk, red. W. Górowski et al., Warszawa 2013.

Merc E., Szkoty prawnicze, „Demokratyczny Przegląd Prawniczy” 1949, nr 3.

Olszewski H., Ludzie uniwersytetu w mojej pamięci, Poznań 2015.

Olszewski H., Profesor Andrzej Ajnenkiel (1931-2015), „Czasopismo Prawno-Historyczne” 67, 2015, z. 2.

Olszewski H., Wydział Prawa [Uniwersytetu Poznańskiego] w latach 1919-1999, „Ruch Prawniczy, Ekonomiczny i Socjologiczny" 61, 1999, z. 2.

Olszewski H., Z prac Studenckiego Koła Naukowego historyków prawa Uniwersytetu Poznańskiego, [w:] Studia i Materiały do Dziejów Wielkopolski i Pomorza, red. Z. Kaczmarczyk, t. 1, Poznań 1956.

Protokoły Senatu i Rady Wydziału UP, Arch. UAM.

Protokót Senatu UP, Kronika Uniwersytetu Poznańskiego 1945/45-1954/55, Arch. UAM, protokoły senatu.

Reszczyński J., Wiesław Litewski (1933-2004), „Czasopismo Prawno-Historyczne” 67, 2005, z. 1.

Rozporządzenie ministra oświaty z 23 grudnia 1949 r. w sprawie organizacji i planu studiów na wydziałach prawa w państwowych szkołach akademickich (Dz.U. z 1950 r. Nr 6, poz. 58).

Rozporządzenie Ministra Wyznań Religijnych i Oświecenia Publicznego z 16 października 1920 r. (Dz.Urz. Ministra Wyznań Religijnych i Oświecenia Publicznego z 1920 r. Nr 22, poz. 140).

Siewierski M., O reforme programu akademickich studiów prawnych i ekonomicznych, „Państwo i Prawo" 1946, z. 2.

Salomonowicz S., Życie jak osioł ucieka. Wspomnienia, Gdańsk 2014.

Szarysz J., Sędziowie i sady w Polsce w latach 1944-1988, Warszawa 1988.

Taylor E., Poznańskie Studium Ekonomiczne 1919-1949, „Ruch Prawniczy i Ekonomiczny” 20, 1958, z. 1.

Uniwersytet Wrocławski 1945-1970. Ksiegga jubileuszowa, red. W. Flora, Wrocław 1970.

Uruszczak W., Stanisław Płaza (1927-2006), „Czasopismo Prawno-Historyczne” 58, 2006, z. 1.

Wąsowicz M., Laudacja w zwiazku z odnowieniem doktoratów Profesor Katarzyny Sójki-Zielińskiej i Profesora Stanisława Salmonowicza, „Czasopismo Prawno-Historyczne” 64, 2012, z. 2.

Witkowski W., Władysław Ćwik (1929-2009), „Czasopismo Prawno-Historyczne” 62, 2010, z. 2.

Wołodkiewicz W., Czy prawo rzymskie będzie istnieć? Uwagi na marginesie nowych prac nad reformowaniem studiów wyższych, „Palestra” 2012, nr 9-10.

Wołodkiewicz W., Nauczanie prawa - między wymaganiami teorii i praktyki, Warszawa 1991.

Zaborski M., Szkolenie sędziów „,nowego typu” w Polsce Ludowej, „Palestra” 1998, z. 3-4.

Ziemba Z., Przygotowanie i rozwój kadr sądownictwa Polski Ludowej, [w:] XXV lat wymiaru sprawiedliwości PRL, red. S. Jabłoński, Warszawa 1969. 
SOME REMARKS ON THE GRADUATE LAW PROGRAMME IN 1952-1954

\section{Summary}

The article is an analysis of graduate law programmes at Polish universities in 1952-1954. Drawing on the literature and sources, the author examines the changes taking place in the education of lawyers during the period of Stalinist indoctrination. He analyses the two-tier programme of studies and concludes that despite its political connotations the programme was not without some achievements. The most important among them was that it educated a valuable generation of law historians making up for the losses suffered by the profession during the Second World War and in the first few years after it ended.

Keywords: law in totalitarianism, education of lawyers, history of law.

Henryk Olszewski

holsz@onet.pl 